\title{
VERIFICATION OF ORTHOTROPIC MODEL OF WOOD
}

\author{
P. OBARA ${ }^{1}$
}

The paper is dedicated to the discussion of elastic coefficients of wood. Parameters for wood presented in the literature are critically evaluated and discussed. The orthotropic mathematical model, with nine different elastic parameters, is one of the most often used models of wood. However, mathematical limitations on these parameters for the correct model are not well known. Based on these limitations, the verification of orthotropic elastic parameters for different species of wood is presented. The analysis shows that the published data are often unclear and sometimes wrong. The attempt to relate experimental results to the mean values specified in the standards is the second aspect considered in this paper. The designer, a user of these standards, should have clear information that the given parameters are specified for specific mathematical model and species of wood. This paper attempts to propose such a classification.

Keywords: wood, orthotropic model, elastic coefficients, limitations

\section{INTRODUCTION}

Wood and wooden products are very popular materials used in construction engineering for buildings, bridges, towers and other structures. Wood is a complex, inhomogeneous and anisotropic material, but in engineering practice wood is often idealized as a homogeneous, orthotropic material $[2,13,14,26,40,44,45]$. Based on the orthotropic model, three principal orthogonal directions of elasticity for wood, i.e., longitudinal $(L)$, tangential $(T)$ and radial $(R)$ are determined. In some papers $[11,24,37,38]$, mostly in numerical simulation, nine independent elastic constants such as three elastic moduli $\left(E_{L}, E_{T}, E_{R}\right)$, three transverse elastic moduli $\left(G_{L T}, G_{T R}, G_{R L}\right)$ and three Poisson's ratios $\left(v_{T R}\right.$, $\left.v_{T L}, v_{R L}\right)$ are defined. In experimental studies [10,12,17,23,27,29,31,33,39] twelve elastic constants, with six different Poisson's ratios $\left(v_{T R}, v_{T L}, v_{R L}, v_{R T}, v_{L T}, v_{L R}\right)$, are determined. According to the

\footnotetext{
${ }^{1}$ PhD., Kielce University of Technology, Faculty of Civil Engineering and Architecture, Al. Tysiąclecia Państwa Polskiego 7, 25-314 Kielce, Poland, e-mail: paula@tu.kielce.pl
} 
orthotropic model, these parameters should satisfy the condition of the symmetry thus nine of these constants are independent. This paper demonstrates that the elastic matrix symmetry condition is not always satisfied. In same papers the orthotropic model of wood is expanded to the model that assumes identical properties in the radial and tangential directions. For this case, six elastic constants are defined [8,19]. In paper [28] authors described wood using a model with four elastic constants. Unfortunately, not all parameters of wood are always stated in the papers. For example, in [4,7,32] there are three elastic moduli and six Poisson's ratios but in [18] - only three elastic moduli and three shear moduli. In none of these cases it is possible to verify the model of wood.

This article attempts to verify the orthotropic model of wood on the basis of the research papers above and wood handbooks $[15,22]$ contents. A general scheme of criteria is offered for checking whether the material constants satisfied the condition of the symmetry of compliance matrix. Over a dozen species of wood are analysed. The second purpose of this paper is to classify the wood species analysed according to European code [34,35].

\section{MATERIALS AND METHODS}

The present paper focuses on the orthotropic model of wood. The considerations are carried out in the Cartesian rectangular coordinate system $x_{1} x_{2}, x_{3}$, coincident with the $L, T, R$ local system. The constitutive equations for linear elastic materials $[1,5,6,9,27]$ are expressed as:

$$
S_{i j}=D_{i j k l} E_{k l} ; i, j, k, l=1,2,3
$$

where:

$S_{i j}$ - component of the symmetric stress tensor, $E_{k l}$ - component of the strain tensor, $D_{i j k l}$ - component of the fourth-order elasticity tensor.

In engineering practice, the convenient two-index notation, referred to as Voigt notation, is used. Then the equation (2.1) takes the form:

$$
s_{i}=d_{i j} e_{j} \text { or } e_{i}=c_{i j} s_{j} ; i, j=1,2, \ldots, 6 \text {, }
$$

where:

$s_{i}$ - single column stress matrix, $e_{j}-$ single column strain matrix, $d_{i j}-$ stiffness matrix and $c_{i j}$ - compliance matrix. 
In general, a stiffness matrix and a compliance matrix contain 36 independent components, but taking into account the symmetry of strain energy, 21 distinct components can be set out. This is the most general case of a linear elastic material. The number of independent components of these matrices is further reduced if the material has symmetry planes. There are exactly eight different sets of symmetry planes $[5,30,42,43]$.

The purpose of this paper is to discuss the linear elastic orthotropic model along with the elastic coefficients. For this model the compliance matrix $c_{i j}$ has the form:

$$
c_{i j}=\mathbf{c}=\left[\begin{array}{cccccc}
\frac{1}{E_{1}} & -\frac{v_{21}}{E_{2}} & -\frac{v_{31}}{E_{3}} & 0 & 0 & 0 \\
-\frac{v_{12}}{E_{1}} & \frac{1}{E_{2}} & -\frac{v_{32}}{E_{3}} & 0 & 0 & 0 \\
-\frac{v_{13}}{E_{1}} & -\frac{v_{23}}{E_{2}} & \frac{1}{E_{3}} & 0 & 0 & 0 \\
0 & 0 & 0 & \frac{1}{G_{23}} & 0 & 0 \\
0 & 0 & 0 & 0 & \frac{1}{G_{13}} & 0 \\
0 & 0 & 0 & 0 & 0 & \frac{1}{G_{12}}
\end{array}\right] \text {, }
$$

where:

$E_{i}$ - Young's modulus, $G_{i j}$ - Kirchhoff's modulus and $v_{i j}$ - Poisson's ratio defined as the ratio of passive strain component perpendicular to the load $\varepsilon_{j}$ and the active strain component parallel to the load direction $\varepsilon_{i}$ :

$$
v_{i j}=-\frac{\varepsilon_{j}}{\varepsilon_{i}} ; i, j=1,2,3 \text { and } i \neq j
$$

There are twelve material constants in (2.3) but only nine of them are independent because, due to existing symmetry, we can write:

$$
v_{i j}=v_{j i} \frac{E_{i}}{E_{j}}
$$

In most papers, Poisson's ratio is calculated according to (2.4) but some researchers $[2,12,17,20,25,29,31-33]$ determine Poisson's ratio from $v_{i j}=-\varepsilon_{i} / \varepsilon_{j}$. Then the compliance matrix is different from (2.3) and equation (2.5) takes the form:

$$
v_{i j}=v_{j i} \frac{E_{j}}{E_{i}}
$$




\subsection{LIMITATIONS OF TECHNICAL CONSTANTS}

Due to positive-definiteness of the strain energy, the compliance matrix (2.3) must be positivedefinite $[1,3,5,6,9,25,30,41-43,46]$. The matrix is positive-definite if all of the leading principal minors are positive (Sylvester's criterion). This leads to subsequent, known from the literature $[25,27,36,46]$ conditions:

$$
\begin{gathered}
E_{1}>0, E_{2}>0, E_{3}>0, G_{23}>0, G_{13}>0, G_{12}>0, \\
1-v_{12} v_{21}-v_{23} v_{32}-v_{13} v_{31}-2 v_{21} v_{32} v_{13}>0, \\
v_{12} v_{21}<1, v_{23} v_{32}<1, v_{13} v_{31}<1 .
\end{gathered}
$$

Another original way to define limitations of elastic constants is to determine eigenvalues $\lambda$ of the compliance matrix:

$$
\operatorname{det}(\mathbf{c}-\lambda \mathbf{I})=0 .
$$

The compliance matrix is positive-definite if all eigenvalues satisfy the condition:

$$
\lambda_{i}>0 ;(i=1,2, \ldots, 6) .
$$

Obtaining positive eigenvalues is equivalent to the fulfilment of conditions (2.7). In the case of orthotropic material, it is impossible to provide a solution to equation (2.8), but it is possible to study the eigenvalues for the data adopted. For an isotropic material described by Young's modulus $E$ and Poisson's ratio $v$ the solutions of (2.8) are the following:

$$
\lambda_{1}=\frac{1-2 v}{E}, \lambda_{2,3}=\frac{1+v}{E}, \lambda_{4,5,6}=\frac{2(1+v)}{E} .
$$

The condition (2.9) leads to known from the literature [3,27,46] dependences:

$$
E>0 \text { and } v \in(-1.0 ; 0.5) \text {. }
$$

The constraint on Poisson's ratio $(2.11)_{2}$ is true only for isotropic materials. For orthotropic materials this range is much wider. Some researchers $[3,20,25,36,42,43,46]$ focused only on determining the values of Poisson's ratios.

The limitations described above as well as the symmetry condition are the basis for the discussion and verification of the correctness of wood elastic coefficients reported in the literature. 


\subsection{TECHNICAL CONSTANTS OF WOOD IN STANDARDS}

A wooden structure is designed according to standards [34,35]. Wood is allocated into fifteen strength classes: nine for poplar and coniferous species and six for deciduous species. Strength properties such as bending, tension along and across the fibre, and compression along and across the fibre are defined for each class. Also, elastic properties such as the longitudinal elastic modulus $E_{1}=E_{0, \text { mean }}$, the tangential elastic modulus $E_{2}=E_{90, \text { mean }}$, and the mean shear modulus $G=G_{\text {mean }}$, are determined. The standards do not include information about Poisson's ratios and the value of mean shear modulus is not clear as it cannot be interpreted as the mean in terms of the three planes. It should be emphasized that these parameters do not apply in the case of the isotropic description due to the absence of interrelation among the elastic modulus, the shear modulus and Poisson's ratio. The standard does not specify that mean values are specified for orthotropic description. Further considerations assume that this is so. The relationship between the parameters laid down in the standard and the results reported in the literature for orthotropic models remains an open question.

\section{RESULTS AND DISCUSSION}

\subsection{ORTHOTROPIC CONSTANTS FOR WOOD}

This study examines orthotropic conditions for different species of wood and verifies the wood constants given in the reference material. When all elastic constants are given $[7,10,11,12,15,16,21,22,23,29,31,33,39]$ it is sufficient see whether condition (2.9) is met (Table 1, Table 2) because if eigenvalues are positive, the compliance matrix is positive-definite. For incomplete data $[4,15,22]$ the conditions (2.7) are reviewed (Table 3).

This study analyses six species of softwoods and eleven species of hardwoods. The softwoods include Spruce (Picea), Sitka Spurce (Picea sitchensis), Engelman Spruce (Picea engelmannii), Norway Spruce (Picea abies [L]. Karst), Pine (Pinus sylvestris L.) and Western Larch (Larix occidentalis). The hardwoods include Maple (Acer platanoides L.), Sugar Maple (Acer saccharum), Yellow Birch (Betula alleghaniensis), Oak (Quercus), Common Oak (Quercus robur L.), White Oak (Quercus alba), Red Oak (Quercus rubra), Beech (Fagus), European Beech (Fagus sylvatica L.), Black Walnut (Juglans nigra) and White Ash (Fraxinus americana).

The eigenvalues of the compliance matrix for the wood species are positive (Table 1, Table 2) and limitations of technical constants (2.7) are satisfied (Table 3). However some wood specimens cannot 
be referred to as orthotropic as in some cases the compliance matrix is non-symmetric. Black Walnut $[15,22]$, Oak [4] and Beech [4] were found to show orthotropic behavior. If the accuracy of calculation terms of the compliance matrices are reduced, Spruce [4] and Maple [11] can also be assumed to be orthotropic. The elastic constants for Pine in [21] were calculated using the orthotropic material model, assuming the symmetry of the compliance matrix. Orthotropic of the Pine is confirmed by experiments discussed in $[13,14]$. However, in the case of pine analyzed in [4], in which ultrasonic measurements of wood were carried out, the compliance matrix is non-symmetric (Table 3 ). Additionally, Poisson's ratio $v_{12}=1.46$ is more than 3.7 times as high as and Poisson's ratio $v_{32}=0.016$ being almost 29 times less than that given in [21] (Table 1).

Table 1. Off-diagonal terms and eigenvalues of the compliance matrix (2.3) for species of softwood

\begin{tabular}{|c|c|c|c|c|c|c|c|c|}
\hline & \multicolumn{4}{|c|}{ data found in the literature } & \multicolumn{4}{|c|}{ calculations in this paper } \\
\hline & $E_{1}$ & $G_{12}$ & $v_{12}$ & $v_{21}$ & $-c_{12}$ & $-c_{21}$ & $\lambda_{1}$ & $\lambda_{4}$ \\
\hline & $E_{2}$ & $G_{13}$ & $v_{13}$ & $v_{31}$ & $-c_{13}$ & $-c_{31}$ & $\lambda_{2}$ & $\lambda_{5}$ \\
\hline & $E_{3}$ & $G_{23}$ & $v_{23}$ & $v_{32}$ & $-c_{23}$ & $-c_{32}$ & $\lambda_{3}$ & $\lambda_{6}$ \\
\hline & \multicolumn{2}{|c|}{$[\mathrm{MPa}]$} & \multicolumn{2}{|c|}{$[-]$} & \multicolumn{2}{|c|}{$\left[10^{-12} \mathrm{~Pa}^{-1}\right]$} & \multicolumn{2}{|c|}{$\left[10^{-6} \mathrm{~Pa}^{-1}\right]$} \\
\hline \multirow{3}{*}{$\begin{array}{l}\text { Pine } \\
{[21]}\end{array}$} & 6919 & 262 & 0.388 & 0.015 & 56 & 56 & 0.00014 & 0.00382 \\
\hline & 271 & 354 & 0.375 & 0.024 & 54 & 54 & 0.00170 & 0.00423 \\
\hline & 450 & 34 & 0.278 & 0.462 & 1027 & 1027 & 0.00282 & 0.02941 \\
\hline \multirow{3}{*}{$\begin{array}{c}\text { Sitka } \\
\text { Spruce } \\
{[15,22]}\end{array}$} & 11880 & 725 & 0.467 & 0.025 & 49 & 39 & 0.00008 & 0.00138 \\
\hline & 511 & 760 & 0.372 & 0.040 & 43 & 31 & 0.00087 & 0.00216 \\
\hline & 927 & 36 & 0.245 & 0.435 & 469 & 480 & 0.00013 & 0.02778 \\
\hline \multirow{3}{*}{$\begin{array}{c}\text { Sitka } \\
\text { Spruce } \\
{[16]}\end{array}$} & 10820 & 660 & 0.470 & 0.020 & 43 & 43 & 0.00009 & 0.00151 \\
\hline & 470 & 690 & 0.370 & 0.040 & 48 & 34 & 0.00096 & 0.00236 \\
\hline & 840 & 30 & 0.240 & 0.440 & 524 & 511 & 0.00145 & 0.03333 \\
\hline \multirow{3}{*}{$\begin{array}{c}\text { Engelman } \\
\text { Spruce } \\
{[15,22]}\end{array}$} & 9790 & 1175 & 0.462 & 0.058 & 100 & 47 & 0.00009 & 0.00085 \\
\hline & 578 & 1214 & 0.422 & 0.083 & 66 & 43 & 0.00064 & 0.00190 \\
\hline & 1253 & 98 & 0.255 & 0.530 & 423 & 441 & 0.00082 & 0.01020 \\
\hline \multirow{3}{*}{$\begin{array}{c}\text { Engelman } \\
\text { Spruce } \\
{[16]}\end{array}$} & 9800 & 1180 & 0.460 & 0.060 & 103 & 47 & 0.00009 & 0.00085 \\
\hline & 580 & 1220 & 0.420 & 0.080 & 64 & 43 & 0.00064 & 0.00189 \\
\hline & 1250 & 90 & 0.260 & 0.530 & 424 & 448 & 0.00082 & 0.01111 \\
\hline \multirow{3}{*}{$\begin{array}{c}\text { Norway } \\
\text { Spruce } \\
{[17]}\end{array}$} & 12800 & 587 & 0.450 & 0.014 & 35 & 35 & 0.00008 & 0.00170 \\
\hline & 397 & 617 & 0.360 & 0.018 & 29 & 28 & 0.00127 & 0.00295 \\
\hline & 625 & 53 & 0.210 & 0.480 & 768 & 529 & 0.00162 & 0.01887 \\
\hline
\end{tabular}


Table 2. Off-diagonal terms and eigenvalues of the compliance matrix (2.3) for species of hardwood

\begin{tabular}{|c|c|c|c|c|c|c|c|c|}
\hline & \multicolumn{4}{|c|}{ data found in the literature } & \multicolumn{4}{|c|}{ calculations in this paper } \\
\hline & $E_{1}$ & $G_{12}$ & $v_{12}$ & $v_{21}$ & $-c_{12}$ & $-c_{21}$ & $\lambda_{1}$ & $\lambda_{4}$ \\
\hline & $E_{2}$ & $G_{13}$ & $v_{13}$ & $v_{31}$ & $-c_{13}$ & $-c_{31}$ & $\lambda_{2}$ & $\lambda_{5}$ \\
\hline & $E_{3}$ & $G_{23}$ & $v_{23}$ & $v_{32}$ & $-c_{23}$ & $-c_{32}$ & $\lambda_{3}$ & $\lambda_{6}$ \\
\hline & \multicolumn{2}{|c|}{$[\mathrm{MPa}]$} & \multicolumn{2}{|c|}{$[-]$} & \multicolumn{2}{|c|}{$\left[10^{-12} \mathrm{~Pa}^{-1}\right]$} & \multicolumn{2}{|c|}{$\left[10^{-6} \mathrm{~Pa}^{-1}\right]$} \\
\hline \multirow{3}{*}{$\begin{array}{c}\text { Maple } \\
{[11]}\end{array}$} & 13810 & 753 & 0.500 & 0.025 & 37 & 36 & 0.00006 & 0.00133 \\
\hline & 678 & 1013 & 0.460 & 0.044 & 34 & 33 & 0.00041 & 0.00184 \\
\hline & 1311 & 255 & 0.420 & 0.820 & 625 & 619 & 0.00099 & 0.00392 \\
\hline \multirow{3}{*}{$\begin{array}{c}\text { Yellow } \\
\text { Birch } \\
{[15,22]}\end{array}$} & 13900 & 945 & 0.451 & 0.024 & 35 & 32 & 0.00007 & 0.00106 \\
\hline & 695 & 1029 & 0.426 & 0.043 & 40 & 31 & 0.00051 & 0.00186 \\
\hline & 1084 & 236 & 0.426 & 0.697 & 643 & 613 & 0.00097 & 0.00424 \\
\hline \multirow{3}{*}{$\begin{array}{c}\text { Yellow } \\
\text { Birch } \\
{[16]}\end{array}$} & 13850 & 940 & 0.450 & 0.020 & 29 & 32 & 0.00007 & 0.00106 \\
\hline & 690 & 1020 & 0.430 & 0.040 & 37 & 31 & 0.00050 & 0.00187 \\
\hline & 1080 & 240 & 0.430 & 0.700 & 648 & 623 & 0.00098 & 0.00417 \\
\hline \multirow{3}{*}{$\begin{array}{c}\text { Common } \\
\text { Oak } \\
{[39]}\end{array}$} & 12827 & 766 & 0.466 & 0.053 & 84 & 36 & 0.00007 & 0.00142 \\
\hline & 633 & 703 & 0.478 & 0.045 & 33 & 37 & 0.00050 & 0.00183 \\
\hline & 1344 & 337 & 0.371 & 0.621 & 462 & 586 & 0.00130 & 0.00297 \\
\hline \multirow{3}{*}{$\begin{array}{c}\text { European } \\
\text { Beech } \\
\mathbf{1 1 . 3 \%} \\
{[29,31,32]}\end{array}$} & 10560 & 930 & 0.580 & 0.040 & 55 & 55 & 0.00009 & 0.00107 \\
\hline & 730 & 1240 & 0.430 & 0.040 & 26 & 41 & 0.00048 & 0.00156 \\
\hline & 1510 & 380 & 0.310 & 0.610 & 404 & 425 & 0.00081 & 0.00263 \\
\hline \multirow{3}{*}{$\begin{array}{c}\text { European } \\
\text { Beech } \\
\mathbf{1 2 . 5 \%} \\
{[12]}\end{array}$} & 13900 & 855 & 0.240 & 0.090 & 149 & 17 & 0.00007 & 0.00117 \\
\hline & 606 & 1280 & 0.270 & 0.070 & 37 & 19 & 0.00041 & 0.00177 \\
\hline & 1900 & 486 & 0.270 & 0.640 & 337 & 446 & 0.00078 & 0.00206 \\
\hline \multirow{3}{*}{$\begin{array}{c}\text { European } \\
\text { Beech } \\
\mathbf{1 2 . 7 \%} \\
{[31,33]}\end{array}$} & 9560 & 930 & 2.260 & 0.110 & 224 & 236 & 0.00006 & 0.00107 \\
\hline & 490 & 1240 & 0.080 & 0.020 & 9 & 8 & 0.00034 & 0.00219 \\
\hline & 2200 & 380 & 0.230 & 1.020 & 464 & 469 & 0.00081 & 0.00263 \\
\hline \multirow{3}{*}{$\begin{array}{c}\text { Air-dry } \\
\text { Beech } \\
10-15 \% \\
{[10]}\end{array}$} & 16000 & 720 & 0.020 & 0.360 & 419 & 1 & 0.00006 & 0.00139 \\
\hline & 860 & 1010 & 0.038 & 0.430 & 299 & 2 & 0.00041 & 0.00145 \\
\hline & 1440 & 190 & 0.720 & 0.380 & 264 & 837 & 0.00100 & 0.00526 \\
\hline \multirow{3}{*}{$\begin{array}{l}\text { Air-dry } \\
\text { Beech* }\end{array}$} & 16000 & 720 & 0.360 & 0.020 & 23 & 23 & 0.00006 & 0.00139 \\
\hline & 860 & 1010 & 0.430 & 0.038 & 26 & 27 & 0.00041 & 0.00145 \\
\hline & 1440 & 190 & 0.380 & 0.720 & 500 & 442 & 0.00100 & 0.00526 \\
\hline \multirow{3}{*}{$\begin{array}{c}\text { Black } \\
\text { Walnut } \\
{[15,22]}\end{array}$} & 11600 & 719 & 0.632 & 0.035 & 54 & 54 & 0.00008 & 0.00139 \\
\hline & 650 & 986 & 0.495 & 0.052 & 42 & 43 & 0.00050 & 0.00186 \\
\hline & 1230 & 244 & 0.378 & 0.718 & 584 & 582 & 0.00101 & 0.00410 \\
\hline
\end{tabular}


Table 3. Off-diagonal terms of the compliance matrix (2.3) and conditions (2.7) for species of woods

\begin{tabular}{|c|c|c|c|c|c|c|c|c|}
\hline & \multicolumn{4}{|c|}{ data found in the literature } & \multicolumn{4}{|c|}{ calculations in this paper } \\
\hline & $E_{1}$ & $G_{12}$ & $v_{12}$ & $v_{21}$ & $-c_{12}$ & $-c_{21}$ & $v_{12} v_{21}<1$ & \multirow{3}{*}{ Eq. $(2.7)_{2}$} \\
\hline & $E_{2}$ & $G_{13}$ & $v_{13}$ & $v_{31}$ & $-c_{13}$ & $-c_{31}$ & $v_{13} v_{31}<1$ & \\
\hline & $E_{3}$ & $G_{23}$ & $v_{23}$ & $v_{32}$ & $-c_{23}$ & $-c_{32}$ & $v_{23} v_{32}<1$ & \\
\hline & \multicolumn{2}{|c|}{ [MPa] } & \multicolumn{2}{|c|}{$[-]$} & \multicolumn{2}{|c|}{$\left[10^{-12} \mathrm{~Pa}^{-1}\right]$} & \multicolumn{2}{|c|}{$[-]$} \\
\hline \multirow{3}{*}{$\begin{array}{c}\text { Pine } \\
{[4]}\end{array}$} & 6634 & - & 1.460 & 0.025 & 221 & 220 & 0.037 & \multirow{3}{*}{0.949} \\
\hline & 113 & - & 0.337 & 0.016 & 50 & 51 & 0.005 & \\
\hline & 320 & - & 0.535 & 0.016 & 50 & 4735 & 0.009 & \\
\hline \multirow{3}{*}{$\begin{array}{c}\text { Spruce } \\
{[4]}\end{array}$} & 5038 & - & 2.350 & 0.043 & 467 & 466 & 0.101 & \multirow{3}{*}{0.200} \\
\hline & 92 & - & 0.255 & 0.022 & 51 & 51 & 0.006 & \\
\hline & 433 & - & 0.377 & 1.738 & 4014 & 4098 & 0.655 & \\
\hline \multirow{3}{*}{$\begin{array}{c}\text { Western } \\
\text { Larch } \\
{[15,22]}\end{array}$} & 12900 & 890 & 0.276 & - & - & 21 & - & \multirow{3}{*}{ - } \\
\hline & 839 & 813 & 0.355 & - & - & 28 & - & \\
\hline & 1019 & 90 & 0.352 & 0.389 & 382 & 420 & 0.137 & \\
\hline \multirow{3}{*}{$\begin{array}{c}\text { Sugar } \\
\text { Maple } \\
{[15,22]}\end{array}$} & 10250 & 646 & 0.476 & 0.037 & 56 & 46 & 0.018 & \multirow{3}{*}{0.660} \\
\hline & 666 & 1138 & 0.424 & 0.065 & 48 & 41 & 0.028 & \\
\hline & 1353 & - & 0.349 & 0.774 & 572 & 524 & 0.270 & \\
\hline \multirow{3}{*}{$\begin{array}{c}\text { White Oak } \\
{[15,22]}\end{array}$} & 10600 & - & 0.428 & 0.036 & 47 & 40 & 0.015 & \multirow{3}{*}{0.755} \\
\hline & 763 & 912 & 0.369 & 0.074 & 43 & 35 & 0.027 & \\
\hline & 1728 & - & 0.300 & 0.618 & 358 & 393 & 0.185 & \\
\hline \multirow{3}{*}{$\begin{array}{c}\text { Red Oak } \\
{[15,22]}\end{array}$} & 13000 & 1053 & 0.448 & 0.033 & 31 & 34 & 0.015 & \multirow{3}{*}{0.786} \\
\hline & 1066 & 1157 & 0.350 & 0.064 & 32 & 27 & 0.022 & \\
\hline & 2002 & - & 0.292 & 0.560 & 280 & 274 & 0.164 & \\
\hline \multirow{3}{*}{$\begin{array}{c}\text { Oak } \\
{[4]}\end{array}$} & 4745 & - & 0.750 & 0.177 & 158 & 158 & 0.133 & \multirow{3}{*}{0.510} \\
\hline & 1122 & - & 0.823 & 0.242 & 173 & 173 & 0.199 & \\
\hline & 1399 & - & 0.239 & 0.298 & 213 & 213 & 0.071 & \\
\hline \multirow{3}{*}{$\begin{array}{c}\text { Beech } \\
{[4]}\end{array}$} & 9160 & - & 0.900 & 0.102 & 98 & 98 & 0.092 & \multirow{3}{*}{0.492} \\
\hline & 1037 & - & 1.244 & 0.251 & 136 & 136 & 0.312 & \\
\hline & 1851 & - & 0.146 & 0.261 & 141 & 141 & 0.038 & \\
\hline \multirow{3}{*}{$\begin{array}{c}\text { White Ash } \\
{[15,22]}\end{array}$} & 10700 & 824 & 0.440 & 0.051 & 60 & 41 & 0.022 & \multirow{3}{*}{0.684} \\
\hline & 856 & 1166 & 0.371 & 0.059 & 44 & 35 & 0.022 & \\
\hline & 1338 & - & 0.360 & 0.684 & 511 & 421 & 0.246 & \\
\hline
\end{tabular}

In [14] is describing orthotropic elastic behavior of Larch but the analysis in this paper (Table 3) is impossible since only some of the elastic parameters are known. The elastic constants for Spruce reported in [4] almost satisfy the orthotropic conditions (Table 3) but data given in [15-17,22] fail to 
do so (Table 1). The elastic constants for five species of spruce shown are comparable in Table 1 but different in Table 3. The value of longitudinal Young's modulus $E_{1}=5038 \mathrm{MPa}$ is $1 / 2$ the value of the mean in Table $1\left(E_{1, \text { mean }}=11018 \mathrm{MPa}\right)$; the tangential Young's moduli $E_{2}=92 \mathrm{MPa}-1 / 5$ the mean value $\left(E_{2, \text { mean }}=507 \mathrm{MPa}\right)$; the radial Young's moduli $E_{3}=433 \mathrm{MPa}-$ less than $1 / 2$ the mean $\left(E_{3, \text { mean }}=979 \mathrm{MPa}\right)$. In case of Poisson's ratio, the largest differences are for $v_{12}$ and for $v_{32}$. The mean values in Table 1 are the following: $v_{12 \text {,mean }}=0.462, v_{32 \text {,mean }}=0.483$ and the corresponding values in Table 3 are: $v_{12}=2.35$ (five times as big) and $v_{32}=1.738$ (over three times as big).

Similar results are obtained for Beech wood. The elastic constants for beech given in [4] satisfy the orthotropic conditions (Table 3), unlike the data given in [12,29,31-33] (Table 2). Five papers, written by same research team [12,29,31-33] show the results for different moisture contents $11.3 \%, 12.5 \%$ and $12.7 \%$. The results vary because elastic parameters are moisture content-dependent. However, it is hard to understand why at the $12.7 \%$ moisture content Poisson's ratios for beech $v_{12}$ and $v_{32}$ are respectively over nine and almost twice as high as for $12.5 \%$ moisture content; whereas $v_{13}$ for $12.5 \%$ is three times as high as for $12.7 \%$ moisture content.

Table 2 shows elastic parameters for the dry beech $10-15 \%$ given in [10]. The data for Poisson's ratios differ by the order of magnitude given in [12,29,31,32] and there are huge differences in the compliance matrix. In [10] the relationship between elastic constants expressed by Eq. (2.5) but parameters seem to satisfy condition (2.6) (Table 2: results for air-dry beech*).

\subsection{REFERENCE TO VALUES IN STANDARDS}

Table 4. Strength classes of wood [34]

\begin{tabular}{|c|c|c|c|c|c|c|c|c|c|c|c|c|c|c|c|}
\hline & \multicolumn{9}{|c|}{ Poplar and coniferous species } & \multicolumn{6}{|c|}{ Deciduous species } \\
\hline & $\mathrm{C} 14$ & $\mathrm{C} 16$ & $\mathrm{C} 18$ & $\mathrm{C} 22$ & $\mathrm{C} 24$ & $\mathrm{C} 27$ & $\mathrm{C} 30$ & $\mathrm{C} 35$ & $\mathrm{C} 40$ & D30 & D35 & D40 & D50 & D60 & D70 \\
\hline$E_{1}[\mathrm{GPa}]$ & 7 & 8 & 9 & 10 & 11 & 12 & 12 & 13 & 14 & 10 & 10 & 11 & 14 & 17 & 20 \\
\hline$E_{2}[\mathrm{GPa}]$ & 0.23 & 0.27 & 0.30 & 0.33 & 0.37 & 0.40 & 0.40 & 0.43 & 0.47 & 0.64 & 0.69 & 0.75 & 0.93 & 1.13 & 1.33 \\
\hline$G[\mathrm{GPa}]$ & 0.44 & 0.50 & 0.56 & 0.63 & 0.69 & 0.75 & 0.75 & 0.81 & 0.88 & 0.60 & 0.65 & 0.70 & 0.88 & 1.06 & 1.25 \\
\hline
\end{tabular}

The values of longitudinal and tangential moduli of elasticity are the basis for determining the class of wood. The mean elastic parameters for different species of wood, according to standard [34], is showed in Table 4. Classification, however, is neither simple nor clear. As shown in Table 5 species of wood were assigned to particular classes based on mean values of elastic moduli $E_{1}$ and $E_{2}$. The classes obtained with $E_{1}$ vary from those obtained with $E_{2}$. Only for White Oak the class is the same 
- C14. For three species of wood is impossible determining the class of wood - the moduli of elasticity are smaller $\left(\right.$ Spruce $^{2}$ ) or larger (Spotted Gum, Tallowwood) then those given in the classification. Also, it not clear how the shear modulus specified in the standard should be understood if for orthotropic materials as many as three moduli are given.

Table 5. Values of longitudinal $E_{1}$, tangential $E_{2}$ moduli of elasticity for wood and class of wood

\begin{tabular}{|c|c|c|c|c|c|c|c|}
\hline & & $E_{1}[\mathrm{MPa}]$ & $\begin{array}{r}E_{1, \text { mean }} \\
{[\mathrm{MPa}]}\end{array}$ & Class & $E_{2}[\mathrm{MPa}]$ & $E_{2, \text { mean }}[\mathrm{MPa}]$ & Class \\
\hline \multirow{5}{*}{$\frac{n}{0}$} & Spruce $^{1}$ & $8900-11400$ & 10150 & $\mathrm{C} 24$ & $650-832$ & 741 & $>\mathrm{C} 40$ \\
\hline & Spruce $^{2}$ & - & 5038 & $<\mathrm{C} 14$ & - & 92 & $<\mathrm{C} 14$ \\
\hline & Pine $^{1}$ & $8200-13700$ & 10950 & $\mathrm{C24}$ & $312-521$ & 416 & C27,C30 \\
\hline & $\operatorname{Larch}^{1}$ & 12900 & 12900 & C35 & 839 & 839 & $>\mathrm{C} 40$ \\
\hline & $\mathbf{Y e w}^{3}$ & 10500 & 10500 & $\mathrm{C} 22-\mathrm{C} 24$ & 627 & 627 & $>\mathrm{C} 40$ \\
\hline \multirow{10}{*}{ 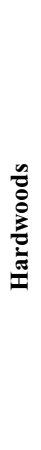 } & Maple $^{1}$ & $7900-12600$ & 10250 & D30-D35 & $514-819$ & 666 & D30-D35 \\
\hline & Birch $^{1}$ & $11000-15000$ & 13000 & D40-D50 & $550-750$ & 650 & D30 \\
\hline & White Oak $^{1}$ & $7100-14100$ & 10600 & D40 & $511-1015$ & 763 & D40 \\
\hline & $\operatorname{Red~Oak}^{1}$ & $10300-15700$ & 13000 & D40-D50 & $742-1130$ & 1066 & D60 \\
\hline & Beech $^{4}$ & $9560-13900$ & 11775 & D40 & $490-606$ & 548 & $<$ D30 \\
\hline & Spotted Gum ${ }^{5}$ & $24467-26512$ & 26147 & $>$ D70 & $1457-1540$ & 1499 & $>$ D70 \\
\hline & Tallowwood $^{5}$ & $20720-21548$ & 21078 & $>$ D70 & $1317-1535$ & 1426 & $>$ D70 \\
\hline & Poplar $^{1}$ & 10900 & 10900 & $\mathrm{C24}$ & 469 & 469 & $\mathrm{C40}$ \\
\hline & Walnut $^{1}$ & 11600 & 11600 & D40 & 650 & 650 & D30 \\
\hline & $\mathbf{A s h}^{1}$ & $9400-12000$ & 10700 & D40 & $752-960$ & 856 & D40-D50 \\
\hline
\end{tabular}

${ }^{1}[22],{ }^{2}[4],{ }^{3}[17],{ }^{4}[12,33],{ }^{5}[7]$

\section{CONCLUSiOnS}

Review of the literature concerning experimental studies of elastic coefficients of wood naturally raises the question of the correctness of the results reported and of the design standard-compliant allocation of a given wood species to appropriate class.

Selected literature data were analyzed with constraints on elastic constants of a linear elasticity orthotropic model as correctness criterion. The results reported are often ambiguous or incorrect with regard to the model adopted. As different methods are used, the comparison of the results is difficult and may lead to the conclusion that the material being examined is not orthotropic. 
The findings of this study indicate that experimental research should be complemented by in-depth theoretical investigations, with special reference to the constraints the results have to meet if they are to be assigned to a certain mathematical model.

Attempts to allocate wood species under this analysis to design classes do not bring conclusive results. The author of this paper believes that three mean values (two elasticity moduli and one shear modulus) are insufficient for a careful reader to be able to verify the results of the experimental work.

\section{REFERENCES}

1. B.D. Annin, N.I. Ostrosablin, “Anisotropy of elastic properties of materials”, Applied Mechanics and Technical Physic 49 (6): 998-1014, 2008.

2. J. Bodig, B.A. Jayne, "Mechanics of wood and wood composites", Van Nostrand Reinhold, New York, 1982.

3. P.H. Boulanger, M. Hayes, "Poisson's ratio for orthorhombic materials", Journal of Elasticity 50: 87-89, 1998.

4. V. Bucur, R.R. Archer, "Elastic constants for wood by an ultrasonic method", Wood Science and Technology 18: 255-265, 1984.

5. P. Chadwick, M. Vianello, S.C. Cowin, "A new proof that the number of linear elastic symmetries is eight", Journal Mechanics Physical Solids 49: 2471-2492, 2001.

6. S.C. Cowin, "A recasting of anisotropic poroelasticity in matrices of tensor components", Transport in Porous Media 50: 35-56, 2003.

7. U. Dackerman, R. Elsener, J. Li, K. Crews, “A comparative study of using static and ultrasonic material testing methods to determine the anisotropic material properties of wood", Construction and Building Materials 102: 963-976, 2016.

8. B. Faggiano, A. Marzo, A. Formisano, F.M. Mazzolani, "Innovative steel connections for the retrofit of timber floors in ancient buildings: a numerical investigation", Computer and Structures 87: 1-13, 2009.

9. J. German, "Podstawy mechaniki kompozytów włóknistych", Politechnika Krakowska, Kraków, 1996.

10. Yu.V. Gorbachev, V.N. Kuznetsov, "Elastic properties of oiled beech wood", Problemy Prochnosti 12: 14-16, 1971.

11. S. Hajdarević, I. Busuladžić, "Stiffness analysis of wood chair frame", Procedia Engineering 100: 746-755, 2015 .

12. S. Hering, D. Keunecke, P. Niemz, "Moisture-dependent orthotropic elasticity of beech wood", Wood Science and Technology 46: 927-938, 2012.

13. G.Y. Jeong, D.P. Hidman, A. Zink-Sharp, “Orthotropic properties of loblolly pine (Pinus taeda) strands", Journal of Materials Science 45: 5820-5830, 2010.

14. G.Y. Jeong, M.J. Park, "Evaluate orthotropic properties of wood using digital image correlation", Construction and Building Materials 113: 864-869, 2016.

15. B. Kasal, "Wood Formation and Properties. Mechanical Properties of Wood", Elsevier, pp. 1815-1828, 2004.

16. J.L. Katz, P. Spencer, Y. Wang, A. Misra, O. Marangos, L. Friis, "On the anisotropic elastic properties of woods", Journal of Materials Science 43: 139-145, 2008.

17. D. Keunecke, S. Hering, P. Niemz, "Three-dimensional elastic behaviour of common yew and Norway spruce", Wood Science and Technology 42 (8): 633-647, 2008.

18. D. Keunecke, W. Sonderegger, K. Pereteau, T. Luthi, P. Niemz, "Determination of Young's and shear moduli of common yew and Norwey spruce by means of ultrasonic waves”, Wood Science and Technology 41: 309$327,2007$.

19. M. Khelifa, N. Vila Loperena, L. Bleron, A. Khennane, “Analysis of CFRP-strengthened timber beams”, Journal of Adhesion Science and Technology 28 (1): 1-14, 2014.

20. C. Kohlhauser, C. Hellmich, "Determination of Poisson's ratios in isotropic, transversely isotropic, and orthotropic materials by means of combined ultrasonic-mechanical testing of normal stiffness: Application to metals and wood", European Journal of Mechanics A/Solids 33: 82-98, 2012.

21. P. G. Kossakowski, "Mixed mode I/II fracture toughness of pine wood", Archives of Civil Engineering 55 (2): 199-227, 2009.

22. D.E. Kreteschmann, "Wood Handbook - Wood as an Engineering Material. Chapter 5, Mechanical Properties of Wood”, Madison, Wisconsin, 2010. 
23. L. Kyzioł,"Zastępcze stałe materiałowe drewna konstrukcyjnego modyfikowanego powierzchniowo PMM", Zeszyty naukowe Akademii Marynarki Wojennej 1 (160): 69-82, 2005.

24. P. Lacki, A. Derlatka, "Analiza numeryczna konstrukcji drewnianej jako struktury ortotropowej”, Zeszyty Naukowe Politechniki Częstochowskiej. Budownictwo 19: 69-76, 2013.

25. B.M. Lempriere, "Poisson's ratio in orthotropic materials", AIAA Journal 6 (11): 2226-2227, 1968.

26. J. Malesza, "Effective model for analysis of wood-framed timber structures", Archives of Civil Engineering 63 (2): 99-112, 2017.

27. N.T. Mascia, E.A. Nicolas, "Determination of Poisson's ratios in relation to fiber angle of tropical wood species", Construction and Building Materials 41: 691-696, 2013.

28. N.T. Mascia, L. Vanalli, "Evaluation of the coefficients of mutual influence of wood through off-axis compression tests", Construction and Building Materials 30: 522-528, 2012.

29. P. Niemz, T. Ozyhar, S. Hering, W. Sonderegger, "Moisture dependent physical-mechanical properties from beech wood in the main directions", PRO LIGNO 11 (4): 37-42, 2015.

30. N.I. Ostrosablin, "Equations of the linear theory of elasticity", Journal of Applied Mechanics and Technical Physics 33 (3): 438-446, 1992.

31. T. Ozyhar, S. Hering, P. Niemz, "Moisture-dependent elastic and strength anisotropy of European beech wood in tension", Journal of Material Science 47 (6): 6141-6150, 2012.

32. T. Ozyhar, S. Hering, P. Niemz, "Moisture-dependent orthotropic tension-compression asymmetry of wood", Holzforschung 67 (4): 395-404, 2013.

33. T. Ozyhar, S. Hering, S.J. P. Sanabria, Niemz, "Determining moisture-dependent elastic characteristics of beech wood by means of ultrasonic waves", Wood Science and Technology 47: 329-341, 2013.

34. PN-EN 338:1999 Timber structures - Strength classes.

35. PN-EN 1995-1-1:2010 Design of timber structures.

36. M. Rovati, "On the negative Poisson's ratio of an orthorhombic alloy", Scripta Mater 48 (3): 235-240, 2003.

37. J. Schmidt, M. Kaliske, "Models for numerical failure analysis of wooden structures", Engineering Structures 31: 571-579, 2009.

38. E. Serrano, "Glued-in rods timber structures - a 3D model and finite element parameter studies", International Journal of Adhesion \& Adhesives 21: 115-127, 2001.

39. J. Smardzewski, "Effect of cyclic wood heterogeneity on the distribution of shear stress in glue bonded joints", Folia Forestalia Polonica 31: 119-130, 2000

40. A. Tabiei, J. Wu, "Three-dimensional nonlinear orthotropic finite element material model for wood", Composite Structures 50: 143-149, 2000 .

41. T.C.T. Ting, "Positive definiteness of anisotropic elastic constants", Mathematic Mechanical Solids 1: 301-314, 1996.

42. T.C.T. Ting, "Very large Poisson's ratio with a bounded transverse strain in anisotropic elastic materials", Journal of Elasticity 77: 163-176, 2004

43. T.C.T. Ting, T. Chen, "Poisson's ratio for anisotropic elastic materials can have no bounds", Quarterly Journal of Mechanics and Applied Mathematics 58 (1): 73-82, 2005.

44. E. Vidal-Salle, P. Chassagne, "Constitutive equations for orthotropic nonlinear viscoelastic behaviour using a generalized Maxwell model. Application to wood material”, Mechanics of Time-Dependent Materials 11: 127142, 2007.

45. S. Vratuša, M. Kitek Kuzman, V. Kilar, "Structural particulars of glued laminated beams of variable height", Drewno 54 (185):19-38, 2011.

46. Q.S. Zheng, T. Chen, "New perspective on Poisson's ratio of elastic solids", Acta Mechanica 150: 191-195, 2001.

\section{LIST OF FIGURES AND TABLES:}

Tab. 1. Off-diagonal terms and eigenvalues of the compliance matrix (2.3) for species of softwood

Tab. 1. Pozadiagonalne wyrazy macierzy podatności (2.3) dla gatunków drewna iglastego

Tab. 2. Off-diagonal terms and eigenvalues of the compliance matrix (2.3) for species of hardwood

Tab. 2. Pozadiagonalne wyrazy macierzy podatności (2.3) dla gatunków drewna liściastego

Tab. 3. Off-diagonal terms of the compliance matrix (2.3) and conditions (2.7) for species of woods

Tab. 3. Pozadiagonalne wyrazy macierzy podatności (2.3) i warunki (2.7) dla gatunków drewna

Tab. 4. Strength classes of wood [34] 
Tab. 4. Klasy wytrzymałości drewna [34]

Tab. 5. Values of longitudinal $E_{1}$, tangential $E_{2}$ moduli of elasticity for wood and class of wood

Tab. 5. Wartości podłużnych $E_{1}$ i stycznych $E_{2}$ modułów sprężystości dla drewna oraz klasyfikacja drewna

\section{WERYFIKACJA ORTOTROPOWEGO MODELU DREWNA}

Słowa kluczowe: drewno, model ortotropowy, współczynniki sprężystości, ograniczenia

\section{STRESZCZENIE:}

Do opisu drewna i materiałów drewnopochodnych najczęściej przyjmowany jest liniowo sprężysty model ortotropowy. W literaturze znajdziemy wiele informacji na ten temat. Nie zawsze jednak informacje te są spójne i zgodne z zasadami teoretycznymi. Dane dostępne w literaturze są często błędne lub niejasne - dlatego sprawdzanie warunków ograniczających na stałe techniczne nabiera szczególnej wartości i pozwala określić ich przydatność.

W niniejszej pracy podjęto próbę uporządkowania rozważań o ortotropowym modelu drewna i podjęto próbę weryfikacji, czy podawane $\mathrm{w}$ literaturze stałe materiałowe spełniają warunki ograniczeń dla stałych technicznych materiału ortotropowego. Oryginalnym sposobem zdefiniowania ograniczeń na stałe techniczne (wynikających z dodatniej określoności macierzy podatności), zaproponowanym w pracy, jest wyznaczenie wartości własnych macierzy podatności. Jeżeli wszystkie wartości własne są dodatnio określone, to macierz podatności jest dodatnio określona. W przypadku materiału ortotropowego nie udaje się podać rozwiązania zagadnienia własnego macierzy podatności w postaci ogólnej, ale można badać wartości własne dla konkretnych danych. Oprócz sprawdzenia ograniczeń na stałe techniczne istotne jest również sprawdzenie, czy otrzymane z badań eksperymentalnych stałe spełniają warunek symetrii macierzy podatności.

W artykule podjęto próbę weryfikacji ortotropowego modelu drewna na podstawie danych literaturowych. Przeanalizowano sześć gatunków drewna iglastego i jedenaście gatunków drewna liściastego (Tabela 1, Tabela 2, Tabela 3). Analiza piśmiennictwa dotyczącego eksperymentalnych badań sprężystych współczynników drewna podnosi kwestię poprawności otrzymywanych wyników. Ponieważ w badaniach stosowane są różne metody, porównanie jest trudne i może prowadzić do wniosku, że badany materiał nie jest ortotropowy. Wyniki analiz otrzymane w tej pracy wskazują, że badania eksperymentalne powinny być uzupełnione dogłębnymi badaniami teoretycznymi, ze szczególnym uwzględnieniem ograniczeń, jakie stałe materiałowe muszą spełnić, jeśli mają zostać przypisane do określonego modelu matematycznego.

Innym dość istotnym problemem jest wykorzystanie stałych materiałowych podanych w literaturze do przypisania, zgodnego z normami projektowania, danego gatunku drewna do odpowiedniej klasy. Wartości podawane w normach dotyczą uśrednionych wartości potrzebnych do projektowania - odniesienie tych wartości do opisu ortotropowego, raportowanego w literaturze, nie jest jednoznaczne i wymaga krytycznego spojrzenia. Projektując konstrukcje drewniane istotne są klasy wytrzymałości i wynikające z nich wartości wytrzymałości na zginanie, rozciąganie i ściskanie. Dla litego drewna konstrukcyjnego określone jest 15 klas wytrzymałości: dla topoli i gatunków iglastych - 9 klas, a dla gatunków liściastych - 6 klas. Dla każdej klasy podano wytrzymałości charakterystyczne na zginanie oraz na rozciąganie i ściskanie wzdłuż i w poprzek włókien. Z właściwości sprężystych podane są wartości średniego podłużnego modułu sprężystości, średniego poprzecznego modułu sprężystości oraz średniego modułu odkształcenia postaciowego (Tabela 4). W normie brak jest informacji o współczynnikach Poissona, a ponadto, nie jest jasne, jak należy rozumieć wartość średniego modułu 
odkształcenia postaciowego, jeśli dla materiałów ortotropowych podano trzy moduły. Przy czym, należy podkreślić, że parametry te nie mają zastosowania w przypadku opisu izotropowego ze względu na brak współzależności między modułem sprężystości, modułem odkształcenia postaciowego i współczynnikiem Poissona. Z normy wynika, że na podstawie danych dotyczących średnich wartości podłużnego i poprzecznego modułu sprężystości należy określić klasę dla analizowanego gatunku drewna. Klasyfikacja ta jednak nie jest jednak prosta i jednoznaczna. W Tabeli 5 podano wartości modułów sprężystości i na tej podstawie próbowano dokonać klasyfikacji drewna. Próby przydzielenia gatunków drewna w ramach tej analizy do klas projektowych nie przyniosły rozstrzygających wyników. Tylko w przypadku białego dębu (White Oak) można jednoznacznie określić klasę drewna - C14. Natomiast w przypadku trzech gatunków drewna niemożliwe jest określenie klasy drewna - moduły sprężystości są mniejsze (Spruce ${ }^{2}$ ) lub większe (Spotted Gum, Tallowwood) niż te podane w klasyfikacji normowej. Dodatkowo należy zwrócić uwagę na to, że dla klas C27 i C30 podane są takie same wartości stałych sprężystych (Tabela 4), a klasy te różnią się właściwościami wytrzymałościowymi. A zatem pojawia się pytanie, czy na podstawie danych materiałowych jest w ogóle możliwa klasyfikacja drewna? Autor tego artykułu uważa, że trzy średnie wartości stałych materiałowych (dwa moduły sprężystości i jeden moduł odkształcenia postaciowego) są niewystarczające, aby uważny czytelnik (projektant) mógł zweryfikować wyniki pracy eksperymentalnej. 